\title{
International youth mobility in Eastern and Western Europe - the case of the Erasmus+ programme
}

\author{
Zsuzsanna Dabasi-Halász ${ }^{1, ¥}$, Katalin Lipták ${ }^{1}$, Julianna Kiss ${ }^{1}$, Ioana Manafi², Daniela Elena \\ Marinescu $^{2}$, Monica Roman ${ }^{2}$, Javier Lorenzo-Rodriguez ${ }^{3}$
}

\begin{abstract}
A country's mobility pattern is largely influenced by its previous historical development and current socioeconomic situation. Hungary and Romania, due partly to the legacy of their socialist past, share many of their social and economic characteristics, which differ from countries in Western Europe. Such differences are also present when looking at the issue of international youth mobility, which contrast not only by rate but also by type in post-socialist countries when compared to Western Europe. The main objective of the present article is to analyse the differences and similarities between Eastern and Western European countries with regard to one mobility programme -Erasmus + . The article presents the differences looking at macro data and quantitative questionnaire data.
\end{abstract}

Keywords: youth; mobility; Erasmus+; post-socialist countries.

\section{Introduction}

Youth mobility and more specifically student mobility are key instruments of European integration and contribute to the personal development of young people. It is therefore strongly supported through a number of EU programmes, and Erasmus+ has been one of the most popular and successful, even if it has different regional magnitude in terms of the number of mobile students (Sanchez Barrioluengo and Flisi, 2017).

General mobility in the European Union is lower than in the rest of the world: only $2.4 \%$ of EU citizens lived (i.e., worked, studied, volunteered, or earned income) in another member state in 2014 (Lee, 2016). In post-socialist countries this ratio was even lower; it did not reach even 0.5 per cent. Among sending countries, however, Poland, Romania, Croatia and Hungary are ranked first (Neubecker, 2014). These statistics also show the correlation of historical development, socioeconomic situation and migration. Such inequalities are also present when looking at the issue of international youth mobility, one of the key issues of all movement within the European Union. The intra-European migration balance for the population aged 16-29 follows a clear centre-periphery pattern, and post-socialist countries are found to be among sending countries (Manafi et al., 2017).

The main objective of the present article is to analyse the differences and similarities between Eastern and Western European countries with regard to the Erasmus + programme. Established in 1987, the Erasmus Student Exchange programme - which used to be study-related at first but then expanded its theme and horizon - is examined in this article because Van Mol (2014) found that

\footnotetext{
¥ Corresponding author: Zsuzsanna Dabasi-Halász, University of Miskolc, Hungary. E-mail: dabasizsuzsa@gmail.com.

${ }^{1}$ University of Miskolc, Hungary, ${ }^{2}$ Bucharest University of Economic Studies, Romania, ${ }^{3}$ Universidad Carlos III de Madrid, Spain.
} 


\section{International youth mobility in Eastern and Western Europe}

creating an 'experience-based social Europe' among mobile students was the result of socialization processes that are characterized by internal and external identity observations, and goes beyond the political unit of the European Union. Although regional differences could be found, these are partially attributed to macro-factors.

We hypothesize that the existing differences between Eastern and Western EU countries regarding the Erasmus ${ }^{+}$programme are related to macro-economic and social factors, but also to institutional ones. We also consider that the heritage of socialism in Eastern European societies plays a role in explaining the low mobility rates from these countries. The main research question is: do the differences related to socio-economic and net migration rate influence the role that a mobility programme, namely Erasmus ${ }^{+}$, plays in different countries?

Our research relies on macro data and also on a micro dataset from a large European research project that covers six countries (the MOVE project - see below). It should be mentioned that due to data limitations, Western European countries are represented here by Germany, Luxembourg, Spain and Norway, while Hungary and Romania are the representatives of post-socialist Eastern Europe. These two countries share the common legacy of socialism, when the free movement of individuals was forbidden; both entered student international mobility flow in the late 1990s. Unlike their Western European peers, student mobility in the two countries is less studied in the international literature and this comparative perspective will provide new insights.

In this article youth mobility is examined by looking at the Erasmus - Erasmus + since 2014 European student exchange programme as a common, homogenous framework for student mobility all over the EU. Knowing the relevance of the Erasmus+ programme for European youth, the article aims at filling the gap regarding the recent characteristics and patterns of Eastern European countries compared to Western Europe, focusing on Romania and Hungary, both of which joined the programme roughly twenty years ago: Romania in 1997 and Hungary in 1998. Using a new dataset produced in 2017, this article also provides a fresh and updated perspective on the current differences and inequalities in students' mobility across Europe.

This article is structured as follows. The first section highlights the role of institutions on youth mobility. Second, the methodological approach and the data are described. Third, a brief perspective on Erasmus + is provided. Fourth, the differences between Eastern and Western countries based on macro data are analysed. Fifth, a closer look at youth mobility using micro data is explained. Finally, concluding remarks follow and future research agenda are suggested.

\section{Theoretical background: Role of Institutions on Youth Mobility}

Recent research emphasizes the role of institutions that influence mobility (Cangià and Zittoun, 2018) and stresses the relevance of a post-colonial heritage (Fechter and Walsh, 2010; Korpela, 2010) to different socio-cultural effects (van Bochove and Engbersen, 2015).

In the literature, studies to identify the determinants of the sending and receiving countries have focused on geographic and historical questions such as whether vicinity (being a neighbouring or nearby country) (Favell, 2008), common cultural elements (religion, culture, language), or a historical past (former colonies, belonging to the same state, important shared events) (Hooghe et al., 2009) influence the individual's decision to choose a particular country as a destination.

Based on the work of Krugman (1991) and Gilpin (2004), institutional economics and one of its branches, evolutionary institutional economics, provide the theoretical foundation for different and similar mobility attitudes of young people from post-socialist countries. Representatives of the new institutional economics theory (most notably North, 1990, 1995; Williamson, 1998, 2000) argue that market behaviour cannot be considered solely as the behaviour of individual actors. In a 
similar manner, student mobility is determined by institutional settings, such as, for instance, those related to curricula, number of semesters spent abroad, agreements between universities, or access to funding. Alongside with the new educational policies and new legal framework put in place in Eastern European countries after the change of the political regime, these settings impact the students' decision to become mobile and affect the magnitude of student mobility at the national level.

In post-socialist countries, in the context of lifting the restrictions on international migration that were present in socialist times (at least officially), the employment rate significantly decreased and open unemployment has since emerged. In terms of mass unemployment following the transition, unemployed workers had more opportunities to seek new jobs, leave the labour market (early retirement) or migrate (Hamberger, 2001). The borders that opened up in the Eastern European countries created new opportunities for both outward and inward migration. Migration was no longer a one-time and one-way journey; open borders became natural for the people in Eastern Europe (Hárs, 2015), allowing them to enjoy new opportunities offered by international mobility.

Following institutional theory, we present a closer look at the differences between postsocialist and non-post-socialist countries regarding mobility, including study-related mobility in the framework of the Erasmus + programme. When examining the mobility of young people Todd et al. (2017) identifies two opposite impacts. On the one hand, mobility can be regarded as a consequence of the everyday life of young people; on the other hand, it may simply be a response to their unfavourable economic circumstances at home. The political situation, historical past and economic development as institutions thus have deterministic effects on mobility (Malaj and de Rubertis, 2017).

\section{Methodology and data}

This article mostly relies on descriptive analysis of macro and micro data, but social network analysis is also applied. First, we look at Eurostat macro data focusing on the six countries involved in the research; we use descriptive statistics in order to examine and characterize their socioeconomic background, which can cause differences in mobility across regions. In the next step, we examine the patterns of mobility for the Erasmus+ students in the EU-EFTA countries (without Lichtenstein and Switzerland, plus Turkey and Macedonia) through network analysis in order to show their main mobility trajectories. The analysis is based on macro socio-economic data collected from the Eurostat database, United Nations (UN) and Organization for Economic Cooperation and Development (OECD), mostly for the 2000-2016 period (not all indicators have available data for this period). For analysis of student mobility, older data were considered in order to characterize general trends. Social network analysis was used, as we consider the relationships and ties with other actors within the network, not the attributes of individuals (Hawe and Ghali, 2008).

The main data used in the framework of this articleis provided by a survey produced within the project MOVE, "Mapping mobility - pathways, institutions and structural effects of youth mobility in Europe", financed through the HORIZON 2020 EU programme (Díaz Catalán et al., 2017). The survey precisely captures the first generation of young people from six European countries born and raised after the change of regime in socialist nations, which led us to the question of whether Erasmus-related mobility differs among countries according to their historical development. One of the aims of the MOVE project was obtaining quantitative data from the young population with mobility experience, considering the research gaps regarding youth and mobility. Given the singularity (a hidden population), we delivered a dual strategy by developing a panel 
survey across the six countries of the consortium $(n=5,499)$ and a snowball survey in order to oversample the mobile population $(n=3,207)$. The respondents were young people aged between 18 and 29 from Germany, Spain, Luxembourg, Norway, Hungary and Romania. The merged data set contains 8,706 respondents: mobiles and non-mobiles. For the purpose of this research, the sample is composed of those respondents who declared having mobility experience $(n=5,275)$ (i.e., they have been abroad longer than two weeks for reasons other than tourism) and have declared the main reason for their mobility as undertaking part of their studies abroad through the Erasmus + programme, resulting in a sample of 1,504 individuals.

\section{The Erasmus programme and Main Destinations of Youth in Europe}

The European Economic Community (EEC) approved an extensive mobility scheme for higher education in 1987, one part of which was the Erasmus programme, which quickly became a strong channel for youth mobility across Europe. Today, Erasmus+ (European Community Action Schemes for the Mobility of University Students) is one of the best-known programmes promoting mobility. Between 2014 and 2020, Erasmus+ plans to give 4 million Europeans a chance to study, train, volunteer or gain professional experience abroad (Erasmus + Annual Report, 2016). Based on the data of the Erasmus+ Annual Report (2016), students from post-socialist countries have lower participation rates in the programme than those in Western Europe, and even though there has been a significant increase, the level of mobility of young people from post-socialist countries is not likely to reach the level of Western countries in the near future. In terms of the absolute number of outgoing students, Spain and Germany are in the lead with an average 34,000 outgoing students per year. Between 2008 and 2015, the values increased by an average of 5.5\% in Germany and by $5.7 \%$ per year in Spain. Hungary produces the smallest average growth, with an average of $0.6 \%$ per year, while in the examined period, the number of outgoing students in Romania increased by an average 9.1\% per year (Erasmus+ Annual Report, 2016).

According to the findings from the social network analysis (see Figure 1), the countries seem to confirm the Centre-Periphery approach (see Manafi et al., 2017) with Eastern European countries grouping together. Spain and Germany are very well-connected countries lying in the heart of the map, followed by Italy, Austria, France and the United Kingdom. Countries which are less wellconnected (the number of edges connecting these countries and other countries is small) are postsocialist countries (Macedonia, Latvia, Estonia, Bulgaria, Hungary and Romania) and two islands, Cyprus and Malta. In Figure 1, the wedges coloured in dark blue represent the most important flows (in per cent), as follows: from Cyprus to Greece (50.2\% of students); from Malta to the United Kingdom (34.8\%); from Slovakia to the Czech Republic (26.59\%); from Luxembourg to Germany (39.60\%); from Macedonia to Turkey (18.18\%); from Turkey to Poland (23.64\%); from Iceland to Denmark (16.20\%); from Luxembourg to France (23.44\%); from Lithuania to Spain (10.94\%); from Spain to Italy (18.93\%); from Italy to France (12.61\%); and from Italy to Germany (11.83\%).

The most popular destination countries of the students of the two post-socialist countries analysed in the article(Hungary and Romania) are diverse. The main destination of the Romanian Erasmus students follows the central-periphery approach (Manafi et al., 2017): Romania is a sending country grouped in the peripheral cluster and the main destinations are found in the central cluster. The main destinations of the Romanian Erasmus+ students are Western European countries, in general, countries where Romance languages are spoken: France (13.53\%), Spain $(11.34 \%)$, Germany (10.58\%) and Italy (9.64\%). An important proportion of Romanian Erasmus students choose to study in Hungary (10.66\%), which, for Romanians, was also one of the top destinations for ethnic and labour migration (Anghel et al., 2016). The main destinations of the Hungarian 
Erasmus students are Germany (20.44\%), Spain (8.82\%), Italy (8.77\%), France (7.56\%), the United Kingdom (6.74\%) and Austria (6.14\%). In addition, our analysis proves that Hungary is also becoming an attractive destination country. Moreover, it confirms that the two former post-socialist countries, Romania and Hungary, have common patterns and their outgoing Erasmus + students prefer similar Western European destination countries, such as Germany, France, Italy and Spain.

Figure 1: "Erasmus+ network" - Strengths of connection between countries in the Erasmus programme (own calculations using data from the Erasmus+ Annual Report 2016 and Gephi 0.9.1 software $)^{1}$

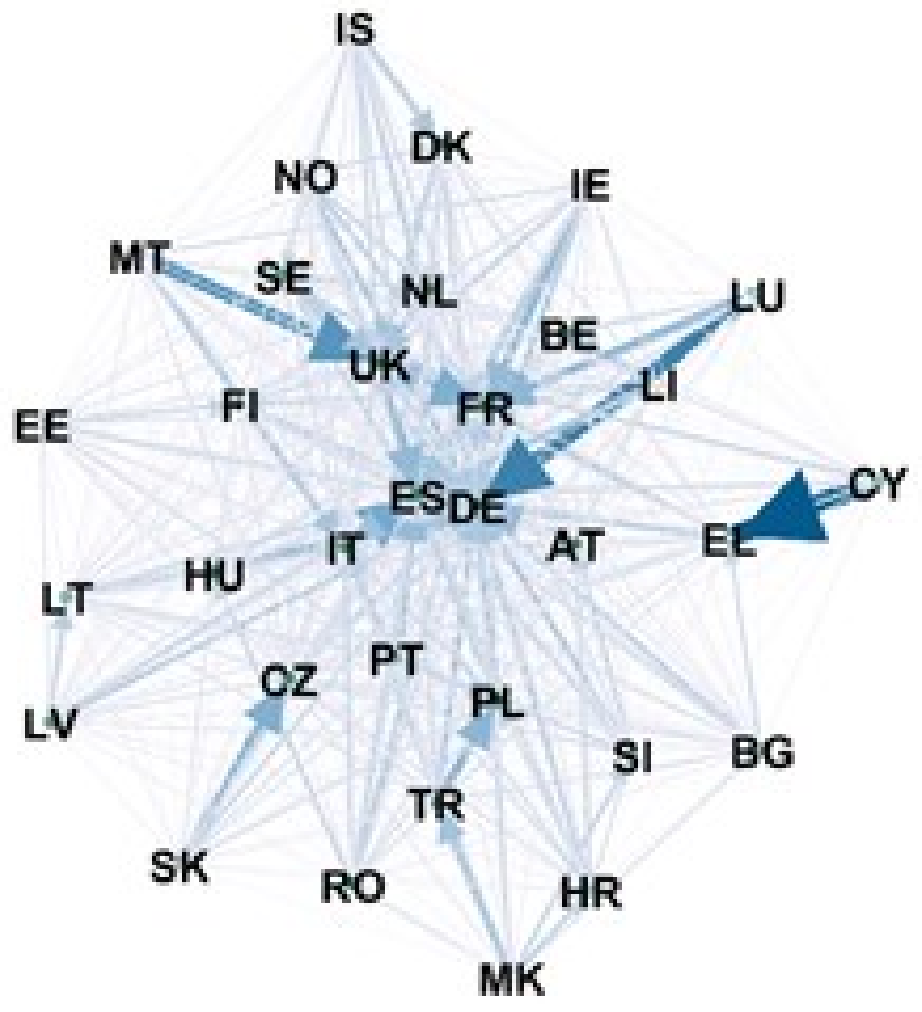

Young generations growing up in today's post-socialist countries live in an environment that still bears the mark of the closed nature of the former system (Anghel et al., 2016; Fischer, 2016). Closed borders during the pre-transition period (before 1989) meant that mobility was not possible for their parents' generation or the generation before that. Thus, in the societies living in post-

\footnotetext{
${ }^{1}$ Mapping the mobility of the Erasmus Exchange Programme in the European Union is carried out using the software Gephi 0.9 .1 and the Force Atlas 2 Layout. ForceAtlas2 is a force directed layout: it simulates a physical system to spatialize a network. Nodes repulse each other as if they were charged particles, while edges attract their nodes. These forces create a movement that converges to a balanced state. Abbreviations used: AT-Austria, BE-Belgium, BG-Bulgaria, CY-Cyprus, CZ-Czech Republic, DK-Denmark, DE-Germany, EEEstonia, EL-Greece, ES-Spain, FI-Finland, FR-France, HR-Croatia, HU-Hungary, IE-Ireland, IS-Island, IT-Italy, LV-Latvia, LTLithuania, LU-Luxembourg, MK-Macedonia, MT-Malta, NL-Netherlands, NO-Norway, PL-Poland, PT-Portugal, RO-Romania, SISlovenia, SE-Sweden, SK-Slovakia, TR-Turkey, UK-United Kingdom.
} 
socialist countries, mobility networks have not fully developed yet and the absence of previous mobility models and pattern might hamper the mobility of young people today. After the change of regime, borders were opened and state control of outgoing mobility almost disappeared, so the postsocialist countries started to re-engage in international migration. As Papatsiba (2006) argued, promoting student mobility was not an act of a limited ambition, but on the contrary, it was an initiative aiming at building the foundation of a modern system of higher education institutions, developed at European standards.

\section{Differences between Eastern and Western countries based on macro data}

This section analyses the relevant socio-economic differences among European countries focusing on the six countries mentioned above - that could influence the development of the Erasmus + programme in these countries. This approach is in line with other studies on migration, as macro-economic context shapes the intensity of youth mobility and affects their mobility patterns. In our opinion, the migration environment (meaning the culture of migration, i.e. the extent and frequency of migration) significantly influences study-related mobility as well (Massey et al., 1987; Alarcón, 1992). Therefore, we analyse migration processes in the countries included in the survey below.

Mayda (2010) analysed the effect on migration of average income and income dispersion in destination and origin countries. Using a pool cross-sectional time series analysis, Jennissen (2003) proved that GDP per capita has a positive effect and unemployment has a negative effect on a country's net international migration. González et al. (2011) studied the determinants of international student mobility flows in Erasmus + programmes. The significant determinants, besides GDP, were found to be country size, cost of living, distance, migration, educational background, university quality, the host country language and climate, as well as the country's characteristics and time effects. As previously mentioned, this section relies on data provided by Eurostat, the UN and the OECD. General migration is examined to determine the pattern migration for each of the six countries highlighting the peaks and important events that influenced.

Looking at the labour market context, we notice that young people aged between 15-29 years neither in employment nor in education and training (NEET rates) registered for Romania and Hungary have ratios above the EU28 average while Germany, Norway, Spain and Luxembourg scored lower. Concerning the activity rate, we find similar results when looking at the differences between Romania and Hungary, on the one hand, and the Western European countries on the other hand. As for the average compensation of employees per hour worked (expressed in euro), the differences are quite clear: while the EU28 average compensation increased, in Romania and Hungary the same indicator also increased but still scored well below the average. In Spain, the values are also below the EU28 rates, while in Germany, Luxembourg and Norway are well above the EU28 average. Furthermore, both Hungary and Romania have annual levels above the European average for the share of people at risk of poverty or social exclusion in the total population. Regarding life expectancy at birth (years) during 2005-2015, Romania and Hungary registered low rates each year, ranking at the bottom within the EU member states. Expenditure on social protection per inhabitant (in purchasing power standard, available data from 2008 to 2014), GINI index and Gross Domestic Products (GDP) per capita expressed in purchasing power standards show similar differences between the post-socialist and other countries, being lower for the first group.

General migration is measured by the crude rate of net migration, defined as the ratio of net migration during the year to the average population in that year (Eurostat 2018) (being calculated as the difference between the total change and the natural change of the population). On average, at 
EU28 level, the crude rate of migration is positive, meaning that there are more immigrants than emigrants at the EU level. The EU28 rate had a quite stable trend during 1992-2001, followed by an increase during 2002-2007, peaking in 2013 and in 2015, according to Eurostat data (see Figure 2).

Figure 2: The crude rate of net migration plus statistical adjustment (per 1,000 persons): 1990-2016 (Source: Eurostat)

Crude rate of net migration plus statistical adjusment (per 1000 persons)

30.0

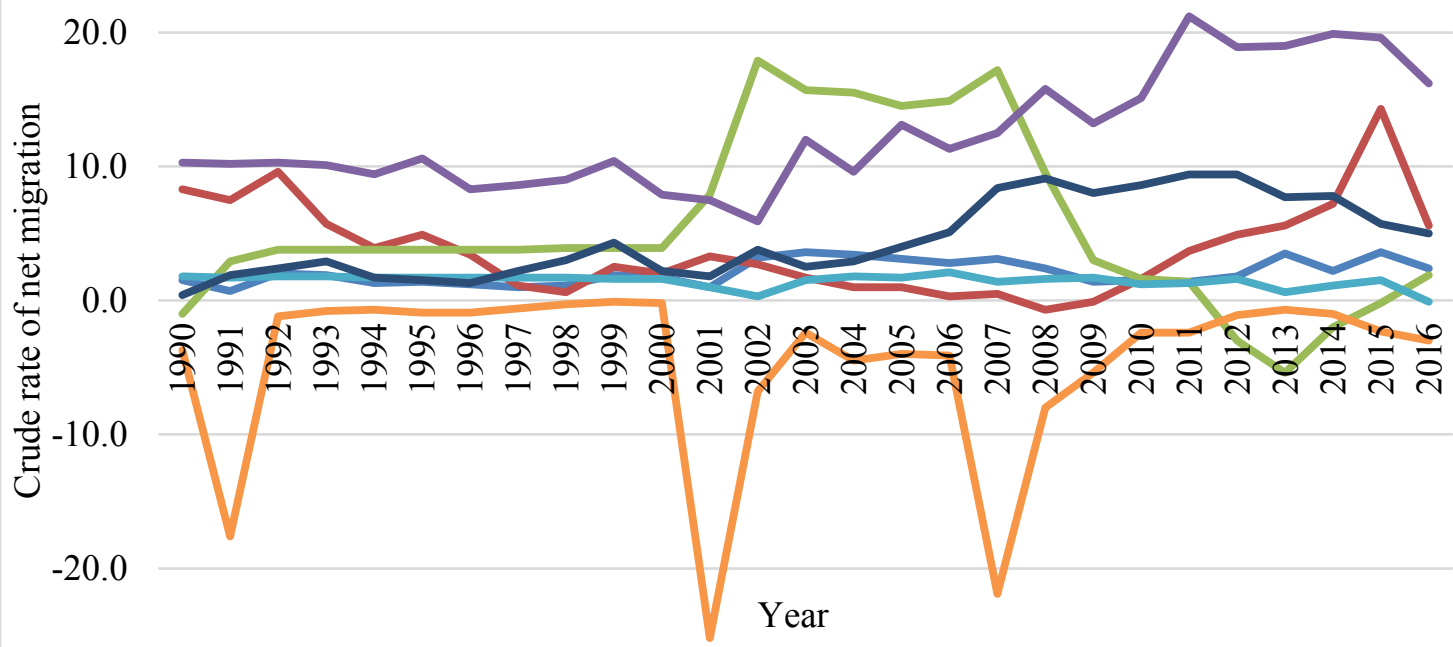

$-30.0$

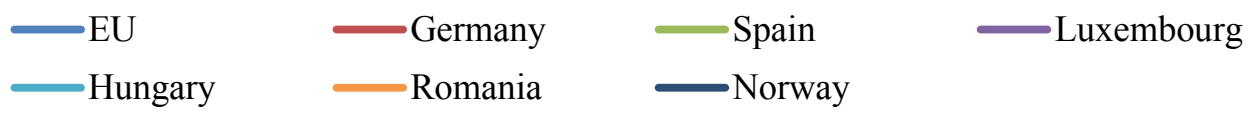

In Hungary, the crude rate of net migration remained stable during 1990-2016. The lowest values were registered in 2002, 2013 and 2016; its highest value was reached in 2006. Romania is the only country (out of the countries examined) to have a very different pattern for the crude rate of net migration. The indicator has negative values during the whole period; as Figure 2 shows, the lowest rates were recorded in 1991 - a year after the fall of the iron curtain, 2001-2002 - when the Schengen countries removed visa requirements, and 2007-2008 - the start of the economic crisis. Spain was more a receiving rather than a sending country until 2011, with the crude rate having only positive values. In 2012 the country transformed into a sending country, the crude rate holding negative until 2016 and reaching its lowest value in 2013. After being a net receiving country during 1990-1996, Germany had a declining crude rate of net migration between 1998 and 2006 (with minor variations). In the last period Germany is still a receiving country, recording the second highest rate in 2015. In Norway, the rate of crude migration has only positive values. During 1990- 
2005 the rate varied, but for 2006-2012 the indicator increased and in recent years the trend has slightly decreased. In Luxembourg the crude rate of net migration shows large variations over the period but the annual rates are well above the EU28 average and are the highest in the EU28, apart from the period 2001-2007, when Spain had the highest ratios.

As we can see, there are relevant differences among the countries examined based on socioeconomic macro data. Thus, the question arises: do these differences influence the role that a studyrelated mobility programme, namely Erasmus ${ }^{+}$, plays in the different countries? In the following section, we will try to answer this question.

\section{Similarities and differences in Erasmus-related mobility}

In this section, we present the main differences and common trends among Hungarian, Romanian and Western European youth when choosing Erasmus programs to move abroad. We analysed the results of the panel survey of the MOVE questionnaire about principal motivations and expectations, satisfaction with the experience and the main barrier and fostering factor in all mobility types, such as previous knowledge of a foreign language or interest in acquiring it. Furthermore, the main inequalities come from family background, economic aspects and other obstacles that respondents faced before and after their mobility experience. In general, according to our findings, young Hungarians and Romanians can be regarded as less internationally mobile than the overall average. The most common mobility types in these two countries in our nonrepresentative sample are related to work. Improving their work conditions and the general financial situation in their own country is more important for respondents from these countries than in Western Europe. Thus, mobility differs not only by rate but also by type in post-socialist countries when compared to Western Europe. Still, participation in Erasmus + can be regarded relevant in all countries. The differences in socio-economic conditions between Eastern and Western Europe might explain the prevalence of mobility related to work in Hungary and Romania.

The main reason for analysing the Erasmus + higher education mobility programme is because of its role as a policy equalizer programme, providing similar opportunities for European youth regardless of their home country. Moreover, it is the most common mobility experience reported in the sample in the case of Western European countries, being also the second most preferred mobility programme for Eastern European countries. Hence, it serves as a constant among countries, providing a common baseline for analysing other factors that could explain variation among the Eastern and Western countries included in the sample. However, mobility conditions and public funding access differ from one country to another, and so heterogeneity appears in terms of level of knowledge about the programme's expectations and incentives and in the barriers faced by each individual. The questionnaire covers in detail the most relevant aspects of the respondents' mobility experience: mobility type, preferred destinations and length of stay, mobility reasons, barriers, expectations and future plans. It therefore allows for a closer, descriptive analysis of the inequalities between the respondents coming from the two European regions.

Looking at the length of stay for the main period of mobility, some differences among countries are notable. The European Mobility Programme, due to its compulsory extension, provides the longest stay for those countries in which working is the main reason for mobility (Romania and Hungary). However, in Luxembourg, studying abroad for the whole bachelor programme is, by far, the most frequent and longest stay; also in Spain Erasmus mobility seems to be longer than for any other country (a full academic year). Overall satisfaction with the programme is quite high: about $71 \%$ of the Romanian and $72 \%$ of the Hungarian youth rated their experience as very good, outperforming the Western countries apart from Spain. While 20\% of the German respondents 
answered that they had had a bad experience, hardly any of the Romanian, Hungarian and Spanish respondents considered their mobility as Erasmus+ students as a bad experience. However, regarding an additional period abroad, the highest percentage of participants is registered by Germany and Spain - about $42 \%$ and $48 \%$ of respondents, respectively, indicated at least a second mobility, while the proportion of respondents from Romania, Norway, Hungary and Luxembourg having a second mobility was $29-35 \%$. This observation confirms the equalizing role of Erasmus + and its capacity to incentivize youth to move abroad.

Expectations regarding the acceptance/adjustment into the new society were exceeded for $47 \%$ of the Romanian and German respondents and for a lower percentage (ranging between 29\% and $36 \%$ ) of respondents from the other countries. The personal experience exceeded expectations for half of the respondents from Luxembourg, Norway and Hungary, $60 \%$ of Romanians and $70 \%$ of those from Spain and Germany. Language acquisition as a fulfilled expectation does not vary a lot between the countries (ranging from 30\% to 44\%). The professional experience gained during the studies abroad is reported as exceeding expectation for $32 \%$ of Romanians, $21 \%$ of Hungarians and $17-18 \%$ for the respondents from Norway, Spain, Germany and Luxembourg. When asked about the particular city they chose, the respondents' top answer was common across the different countries. 35\% of Romanians, around $42 \%$ of German, Spanish, Hungarian and Luxembourgish respondents and $63 \%$ of Norwegians answered that they felt attracted to the cultural offerings of the destination city.

Previous knowledge of the language is the most frequent reason to move for $40 \%$ of Luxembourgish youth, $24 \%$ of Romanians, $20 \%$ of German youth, $13 \%$ of Spanish young people, $10 \%$ of Norwegians and $6 \%$ of Hungarians. Also, learning or improving languages is indicated as the most important reason to move to another country by $85 \%$ of Hungarian respondents, $70 \%$ of Germans and Spanish respondents, $62 \%$ of Norwegians, $45 \%$ of Romanians and $32 \%$ of Luxembourgish respondents. The lack of sufficient language skills is indicated as an important obstacle for young people in moving abroad: the percentage ranges between 17\% (Luxembourg) and $32 \%$ (Romania and Germany). The percentage of respondents who had not experienced any barrier is about $20 \%$, irrespective of country of origin.

Generally, the responses regarding the decision-making process for enrolling in an Erasmus + Higher Education programme are quite similar, irrespective of the country of origin: around $90 \%$ of respondents (96\% in Hungary and Norway, 93\% in Spain, 91\% in Romania, $89 \%$ in Germany and $82 \%$ in Luxembourg) answer that the decision to go abroad was their own. Friends, parents or partners had very little influence. Only $4 \%$ of the young Romanians and $9 \%$ of the Spanish respondents had parents who had studied abroad, while $12 \%$ of the Hungarian and German youth did . By contrast, the corresponding percentage is quite high for Luxembourgish respondents (24\%) and Norwegians (27\%). The respondents of all countries involved, apart from Romania, indicated a high rate of friends doing student exchange, so the role of informal networks is significant, but possibly less important in post-socialist countries.

The European mobility programmes are important as a source of financing the stay abroad as Erasmus+ students for Romanian and Hungarian youth. $81 \%$ of them have used this type of financing, almost double the percentage compared to that of Spain, Germany, Luxembourg and Norway. Family assistance is also a source of financing studies abroad for $44 \%$ of Romanian and German respondents, $47 \%$ of the Hungarian and Luxembourgish respondents and $75 \%$ of respondents from Spain, but for only $9 \%$ of Norwegians. While $25 \%$ of Romanians and $15 \%$ of Hungarians reported that they were traveling by bus to the country of study, the percentage of the 
respondents from the rest of the countries doing the same is quite low ( $7 \%$ for Luxembourg, $5 \%$ for Spain, 4\% for Germany and 3\% for Norway). Romanians and Hungarians are more likely to compensate for the lack of national funding by working full or part-time during their period abroad than westerners.

Those results indicate the relevance of institutions and path-dependency when individuals decide to move abroad. Moreover, the fact that respondents using bus as the main transportation system are those from Romania and Hungary highlights the lack of economic resources. While $18 \%$ of Hungarians and $20 \%$ of Romanians are very likely to move to another part of the country they currently live in, the corresponding percentage of the respondents from Germany, Spain, Luxembourg and Norway is around $31-36 \%$. Also, the young people most likely to move to another country are the Spanish respondents, $(45 \%)$, followed by the Romanian (33\%), Hungarians and Norwegians (29\%), Germans (21\%) and those from Luxembourg (16\%).

When analyzing the numbers for the two Eastern European countries, some interesting results can be found. A high percentage of both Romanian and Hungarian respondents rated the experience of being an Erasmus + student as very good. The expectations before their stay were exceeded when thinking about their personal experience and, to a lower extent, regarding education and training. They perceived the same obstacles faced when moving abroad: the lack of sufficient language skills and the lack of support or information. However, when asked about the future, young people from Romania and Hungary were less likely to move to another country or to another part of their own country than Western European counterparts. The decision to go abroad for study is mainly an individual decision, but still influenced by parents' or friends' recommendations to study abroad. Also, there are similarities regarding the form of financing, with most Romanian and Hungarian respondents indicating the European mobility programmes as the most important source of financing, the second being family assistance. In Romania, the family's influence on the decision to move abroad is higher than in other countries; the parents' recommendations to study abroad and their support played a particularly important role on young people's decision to move abroad.

\section{Conclusions}

Youth intra-European mobility and student mobility in particular are among the most vibrant European movements, with clear positive impacts at individual and social level (Roman and Suciu, 2007). The Erasmus + programme acts as the leading funding instrument for such a mobility type, providing a homogeneous frame for equal access to funding for youth all over Europe. However, differences between European regions are still significant (Sanchez Barriolueng and Flisi, 2017). Adopting institutional theory, the article explores the inequalities between Eastern and Western European countries related to Erasmus + youth mobility; Romania and Hungary, two post-socialist countries, are compared with Germany, Luxembourg, Spain and Norway.

Using a descriptive approach, the characteristics of mobile youth are further compared, based on a large dataset consisting in 1,504 individuals aged 18-29 that have used Erasmus+ mobility programme. The analysis reveals interesting conclusions in terms of both differences and similarities of individuals' behaviour related to their mobility.

As expected, there are clear differences between post-socialist Eastern countries and Western countries regarding their current socio-economic situation. The existing gap in terms of labour market conditions and economic development might explain the differences in the mobility type most preferred by European youth: the Eastern European youth prefer mobility for work-related reasons, followed by study-related mobility such as that supported by Erasmus+, while Western European youth enjoy mobility for study in the first place. 
Young Hungarians and Romanians can be regarded as less internationally mobile than the overall European average. They have similar mobility trajectories and the most preferred destinations are Germany, France, Spain and also the UK.

In terms of the decision to become mobile, the respondents show similar behaviour and they individually make the decision to move abroad, even if there are differences related to their network of mobile persons: Romanians are more influenced by families and have the lowest share of friends or parents that have studied abroad, while Hungarians have a larger international network for studying abroad.

The Eastern Europeans seem more enthusiastic and rate their experience more highly as compared to participants from Western countries, This positive assessment of the Erasmus+ experience should be regarded in the context of a less favourable financial context: Eastern European youth were supported to a higher extent by their families and also due to financial reasons they travelled to destination by bus in a larger share than their Western peers. To compensate for the lack of financial resources, they took jobs during the mobility.

The results of this study provide initial evidence that Erasmus students in Eastern European countries present both similarities and differences related to their mobility experience with participants originating from Western Europe. However, this conclusion needs further attention and opens room for further research. The analysis needs to be extended in order to provide insights on the factors that contribute to homogenizing or differentiating European youth behaviour related to their intra-European mobility; for instance, the number of mobility experiences or the role of the culture of mobility or families could be further explored. The contribution of the Erasmus + programme to this outcome and to a real integration of Erasmus + students in a vibrant Europe needs to be further investigated, for instance by analysing the impacts of this major programme on human capital accumulation, on personal development and on the economic status of European youth.

\section{References}

Alarcón, R. (1992): Nortenización: Self-perpetuating migration from a Mexican town. In J. Bustamante, R. Hinojosa and C. Reynolds (eds.): U.S.-Mexico Relations: Labor Market Interdependence. Stanford University Press, Palo Alto, CA, 302-318.

Anghel, R. G., Botezat, A., Coșciug, A., Manafi, I., and Roman, M. (2016). International Migration, Return Migration, and their Effects: A Comprehensive Review on the Romanian Case. IZA Discussion Paper No. 10445. https://ssrn.com/abstract=2895293

Bochove, van M. and Engbersen, G. (2015). Beyond Cosmopolitanism and Expat Bubbles: Challenging Dominant Representations of Knowledge Workers and Trailing Spouses. Population, Space and Place, 21(4), 295-309.

Cangià, F., and Zittoun, T. (2018). When "expatriation" is a matter of family. Opportunities, barriers and intimacies in international mobility, Migration Letters, 15(1), 1-16. DOI: https://doi.org/10.33182/ml.v15i1.336

Díaz Catalán, C., Díaz Chorne, L., Fernández Araiz, V., Lorenzo Rodríguez, J., Navarrete Moreno, L., Pallar' es Cardona, E., and Sanz Suárez-Lledó; V. (2017): Mapping mobility-pathways, institutions and structural effects of youth mobility. Deliverable D.4.5 - Descriptive Analysis Report. https://www.ssoar.info/ssoar/ handle/document/56954\# [accessed 22 April 2018]

Erasmus + Annual Report (2016). https://ec.europa.eu/programmes/erasmus-plus/resources/documents/erasmusannual-report-2016_en [accessed 22 April 2018]

Eurostat (2018): Database. https://ec.europa.eu/eurostat/data/database and http://data.europa.eu/euodp/data/publisher/estat [accessed 22 April 2018]

Favell, A. (2008). The New Face of East-West Migration in Europe'. Journal of Ethnic and Migration Studies, 34 (5), 701-716.

Fechter, A.M., and Walsh, K. (2010). Examining "Expatriate" Continuities: Postcolonial Approaches to Mobile Professionals. Journal of Ethnic and Migration Studies, 36(8), 1197-1210. 


\section{International youth mobility in Eastern and Western Europe}

Fischer, L. P. (2016). Symbolic Traces of Communist Legacy in Post-socialist Hungary: Experiences of a Generation that Lived During the Socialist Era. Leiden: Brill.

Gilpin, R. (1987). The Political Economy of International Relations, Princeton: Princeton University Press.

González, C. R., Mesanza, R. B., and Mariel, P. (2011). The determinants of international student mobility flows: an empirical study on the Erasmus programme, Higher Education, 62(4), 413-430.

Hamberger, J. (2001). Rendszerváltás és az állam felbomlása (Regime Change and the Dissolution of the State), História, 23(9-10), 38-41.

Hárs, Á. (2015). Elvándorlás és bevándorlás Magyarországon a rendszerváltás után - nemzetközi összehasonlításban, In Fazekas K. (Ed): Munkaerőpiaci Tükör 2015, 39-53.

Hawe, P., Ghali, L. (2008). Use of social network analysis to map the social relationships of staff and teachers at school, Health Education Research, 23(1), 62-69.

Hooghe, M., Reeskens, T., Stolle, D., and Trappers, A. (2009). Ethnic Diversity and Generalized Trust in Europe. A Cross-National Multilevel Study. Comparative Migration Studies, 42(2), 198-223.

Jennissen, R. (2003). Economic determinants of net international migration in Western Europe. European Journal of Population/Revue Européenne de Démographie, 19(2), 171-198.

Korpela, M. (2010). A Postcolonial Imagination? Westerners Searching for Authenticity in India. Journal of Ethnic and Migration Studies, 36(8), 1299-1315.

Krugman, P. (1991). Increasing Returns and Economic Geography. Journal of Political Economy, 99(3), 483-499.

Lee, J.J.H. (2016). World Migration Report 2015. Migrants and Cities: New Partnerships to Manage Mobility. IOM Switzerland

Manafi, I., Marinescu, D., Roman, M., and Hemming, K. (2017). Mobility in Europe: Recent trends from a cluster analysis, Amfiteatru Economic 46 (19), 711-726.

Malaj, V., and de Rubertis, S. (2017). Determinants of migration and the gravity model of migration - application on Western Balkan emigration, Migration Letters, 14(2), 204-220.

Massey, Douglas S. and García-España F. (1987): “The Social Process of International Migration,” Science, 237(4816), 733-738,

Mayda, A. M. (2010). International migration: A panel data analysis of the determinants of bilateral flows. Journal of Population Economics, 23(4), 1249-1274.

Neubecker, N., Marcel F., and Carolin L. (2014). Migration in der Europäischen Union, DIW Wochenbericht, Deutsches Institut für Wirtschaftsforschung (DIW), Berlin, 81(30), 711-722.

North, D. C. (1990). Institutions, Institutional Change and Economic Performance. Cambridge: Cambridge University Press.

North, D.C. (1995). The New Institutional Economics and Third World Development. In J. Harriss, J. Hunter, and C. M. Lewis, (Eds.) The New Institutional Economics and Third World Development, New York/London: Routledge, 17-26.

Papatsiba, V. (2006). Making higher education more European through student mobility? Revisiting EU initiatives in the context of the Bologna Process, Comparative Education, 42(1), 93-111.

Roman, M. and Suciu, C. (2007). International Mobility of Romanian Students in Europe: From Statistical Evidence to Policy Measures. Romanian Journal of European Studies, 2(5-6), 167-178.

Sanchez Barrioluengo, M. and Flisi, S. (2017). Student Mobility in Tertiary Education: Institutional Factors and Regional Attractiveness. Publications Office of the European Union, Luxembourg.

Todd, G.J.N., Clark, B., Marston, M., Urassa, M., and Todd, J. (2017). Gender and youth migration for empowerment: migration trends from Tanzania, Migration Letters, 14(2), 300-317.

United Nations (2017), Department of Economic and Social Affairs, Population Division. International Migration Report 2017.

Van Mol, C. (2014). Intra-European Student Mobility in international Higher Education Circuits. Basingstoke: Palgrave Macmillan.

Williamson, O. E. (1998). Transaction Cost Economics: How It Works; Where It is Headed. De Economist, 146 (1), 23-58.

Williamson, O. E. (2000). The New Institutional Economics: Taking Stock, Looking Ahead. Journal of Economic Literature, 38(3), 595-613. 